\title{
PENERAPAN ASAS "PREMIUM REMEDIUM" TERHADAP PERTANGGUNG JAWABAN PIDANA KORPORASI INDUSTRI PERTAMBANGAN DI INDONESIA
}

\author{
Sekhroni.* \\ Mahkamah Agung Republik Indonesia \\ Email:sekhroni@gmail.com
}

\begin{abstract}
Environmental damage caused by industry is increasingly concerned and therefore requires a strong accountability. The formulation of the problem What is the Regulation of Corporate Crime Responsibility in the Mining Industry in Indonesia and How should the law enforcement of economic crimes in the mining industry. The purpose of this study is to determine how the accountability of corporate criminal acts in the mining industry in Indonesia and know How should the law enforcement of economic crimes in the mining industry. The research method used by the researcher is using the normative juridical approach. The results of the Law No. 4 of 2009 on Mineral and Coal Mining apply the principle of remedium premium. It can be seen from the content and general explanation of the two laws does not mention that the two laws are based on ultimum remedium principle. In line with the criminal law doctrine, ultimum remedium means that criminal sanctions are the last option in preventing the occurrence of violations in the mining field. Conclusion To reach the means of dispute resolution within the mining field if it is to provide a deterrent effect (premium remedium) or provide awareness to business offenders, it is better to apply severe criminal sanctions to the perpetrators of such mining crimes.
\end{abstract}

Keywords: Accountability, Criminal Acts, Mining.

\section{Abstrak}

Kerusakan lingkungan yang disebabkan oleh industri semakin memperhatikan oleh karena itu memerlukan pertanggungjawaban yang tegas. Adapun rumusan masalah Bagaimanakah Pengaturan Pertanggung Jawaban Tindak Pidana Korporasi dalam Industri Pertambangan di Indonesia dan Bagaimana seharusnya penegakkan hukum tindak pidana ekonomi dalam industri pertambangan. Adapun tujuan penelitian ini adalah untuk mengetahui Bagaimanakah pengaturan pertanggung jawaban tindak pidana korporasi dalam industri pertambangan di indonesia dan mengetahui Bagaimana seharusnya penegakkan hukum tindak pidana ekonomi dalam industri pertambangan. Metode penelitian yang digunakan oleh peneliti adalah menggunakan pendekatan yuridis normatif. Hasil penelitian Undang-Undang Nomor 4 Tahun 2009 tentang Pertambangan Mineral dan Batu Bara menerapkan asas premium remedium Hal itu terlihat dari isi dan penjelasan umum dari kedua undang-undang tersebut tidak mencantumkan bahwa kedua undangundang tersebut menganut asas ultimum remedium. Sejalan dengan doktrin hukum pidana yaitu ultimum remedium artinya sanksi pidana merupakan pilihan terakhir dalam mencegah terjadinya pelanggaran di bidang pertambangan. Kesimpulan Untuk mencapai sarana penyelesaian sengketa di dalam bidang pertambangan jika ingin memberikan efek jera (premium remedium) atau memberikan penyadaran pada pelaku kejahatan bisnis maka lebih baik diterapkan sanksi pidana seberat beratnya bagi pelaku kejahatan pertambangan tersebut.

Kata kunci : Pertanggung Jawaban, Tindak Pidana Koorporasi, Pertambangan.

\footnotetext{
- Panitera Muda Pidana di Pengadilan Negeri Tegal, Dosen pada STAIBN Tegal, Mahasiswa Program Doktoral Ilmu Hukum UNS Surakarta.
} 


\section{PENDAHULUAN}

Unsur yang fondamental mengenai pemidanaan terletak ada dan tidak adanya kesalahan/guilt yang dilakukan oleh subyek yang mampu bertanggung jawab atas hukum. Siapa dan apapun obyek dari tindak pidana tidak akan memiliki makna hukum pidana tanpa adanya subyek yang mampu bertanggung jawab atas tindakan tersebut. Hal ini sebagai dasar untuk menentukan diproses atau tidaknya, terletak pada mampu atau tidak pertanggungjawabannya.

Pertanggungjawaban pidana (criminal liability) dalam hukum pidana positif saat ini menganut asas kesalahan (guilt) sebagai salah satu asas disamping asas legalitas. Sistem pertanggungjawaban pidana dalam hukum pidana nasional menerapkanasas tiada pidana tanpa kesalahan yang merupakan salah satu asas fundamental yang perlu ditegaskan secara eksplisit sebagai pasangan asas legalitas. Kedua asas tersebut tidak dipandang syarat yang kaku dan bersifat absolut. Oleh karena itu memberi kemungkinan dalam hal-hal tertentu untuk menerapkan asas strict liability, vicarious liability, erfolgshaftung, kesesatan atau error, rechterlijk pardon, culpa in causa dan pertanggungjawaban pidana yang berhubungan dengan masalah subjek tindak pidana. Maka dari itu ada pula ketentuan tentang subjek berupa korporasi. Semua asas itu belum diatur dalam KUHP (Wvs), namun dalam peraturan perundang-undangan lain menentukan korporasi sebagai subyek hukum pidana, seperti dalam Undang-Undang Nomor 32 tahun 2009 tentang Perlindungan dan pengelolaan lingkungan hidup, Undang-Undang No. 4 tahun 2009 tentang Pertambangan Mineral dan Batu Bara dan lain lain.

Negara mempunyai hak menguasai atas bumi, air dan kekayaan alam yang terkandung di dalamnya termasuk tambang. Berdasarkan hal tersebut setiap orang yang akan melakukan pertambangan aturan mainnya wajib meminta izin terlebih dahulu dari Negara/Pemerintah. Apabila terjadi kegiatan penambangan pelakunya tidak memiliki izin atau melakukan kegiatannya yang menyimpang dari aturan ijin tersebut, maka perbuatannya merupakan tindak pidana, bahkan pertanggungjawabannya ditujukan kepada korporasi.

Korporasi dalam sekala besar memberikan arti yang besar bagi dunia. Mereka ada dimana saja, dan hampir di seluruh aspek kehidupan. Korporasi merupakan istilah yang biasa digunakan oleh para ahli hukum pidana dan kriminologi untuk menyebut apa yang dalam bidang hukum lain, khususnya bidang hukum perdata sebagai badan hukum, atau dalam bahasa belanda disebut rechtpersoon atau dalam bahasa Inggris dengan istilah legal person atau legal body. Pengertian subjek hukum pada pokoknya adalah manusia dan segala sesuatu yang berdasarkan tuntutan kebutuhan masyarakat, yang oleh hukum diakui sebagai pendukung hak dan kewajiban. Pengertian yang kedua inilah yang dinamakan badan hukum.Menurut terminologi Hukum Pidana, bahwa 'korporasi adalah badan atau usaha yang mempunyai identitas sendiri, kekayaan sendiri terpisah dari kekayaan anggota.

Berdasarkan uraian tersebut maka akan tampak bahwa pembangunan di bidang ekonomi seperti berdirinya industri-industri baik yang dilakukan oleh investor asing maupun domestik, yang menggunakan alat berat maupun ringan itu sangat berperan dalam perusakan dan atau pencemaran lingkungan apabila dalam pengoperasiannya tanpa mengindahkan peraturan hukum yang ada serta adanya kemauan penegak hukum lingkungan hususnya pertambangan untuk menegakan hukum lingkungan agar pembangunan berkelanjutan akan tercapai. Berdasarkan latar belakang tersebut di atas penulis tertarik untuk menulis makalah yang berjudul : "Penerapan asas "premium remedium" terhadap pertanggung jawaban pidana korporasi industri pertambangan."

\section{RUMUSAN MASALAH}

Berkaitan dengan latar belakang yang telah diuraikan di atas, maka rumusan masalah dalam tulisan ini dirumuskan sebagai berikut:
1. Bagaimanakah Pengaturan Pertanggung Jawaban Tindak Pidana Korporasi dalam Industri Pertambangan di Indonesia? 
2. Bagaimana seharusnya penegakkan hukum tindak pidana ekonomi dalam industri pertambangan?

\section{METODE}

Penelitian yang digunakan oleh penulis adalah yuridis empiris. Data yang digunakan dalam penelitian ini adalah data primer yaitu wawancara dan data sekunder yaitu bahan hukum primer mulai dari UUD 1945, UndangUndang Nomor 4 Tahun 2009 tentang Pertambangan Mineral dan Batu Bara, bahan hukum sekunder berupa jurnal, penelitianpenelitain terdahulu serta buu referensi yang relevan. Metode penelitian hukum, menurut Soerjono Soekanto adalah "suatu kegiatan ilmiah, yang di dasarkan pada metode, sistematika dan pemikiran tertentu, yang bertujuan mempelajari satu atau beberapa gejala hukum tertentu, dengan menganalisanya .

\section{PEMBAHASAN}

\section{Pertanggung Jawaban Tindak Pidana Korporasi dalam Industri Pertambangan di Indonesia}

Fungsi hukum adalah untuk pembaharuan (renew) perilaku masyarakat, maksudnya bahwa hukum harus menjadi instrumen dalam mengarahkan masyarakat untuk menuju kepada tujuan yang diinginkan, bahkan bila perlu, menghilangkan kebiasaan masyarakat yang dipandang negatif. Dengan demikian, artinya ruang lingkup hukum meliputi seluruh aspek kehidupan masyarakat yang ditata oleh hukum. Sebagaimana menurut Roscoe Pound, "bahwa hukum dapat berfungsi sebagai alat untuk pembaharuan masyarakat (law as a tool of social engineering)". ${ }^{1}$

Apa yang harus digarap oleh hukum dalam konteks social engineering itu? jawabannya adalah "menata kepentingan yang ada dalam masyarakat". Kepentingankepentingan tersebut harus ditata sedimikian rupa agar tercapai keseimbangan yang proporsional. Manfaatnya adalah terbangunya

1 Roescoe Pound, 1961, An Introduction to the Philosophy of Law, New Haven, Yale University Press, hal.223 suatu struktur masyarakat sedemikian rupa sehingga secara maksimum mencapai kepuasan akan kebutuhan dengan seminimum mungkin menghindari benturan dan pemborosan. Lalu apa sajakah kepentingan-kepentingan dimaksud ? Pound mengajukan tiga kategori kelompok kepentingan, yaitu kepentingan umum, sosial, dan kepentingan pribadi. ${ }^{2}$

Sebagai pemikir sociological Jurisprudence, Pound mengusulkan agar para ahli hukum beraliran sisiologis perlu lebih memperhitungkan fakta sosial dalam pekerjaannya, apakah pembuatan hukum, penafsiran, atau penerapan peraturan. Sebab bagi Pound, kehidupan hukum terletak pada pelaksanaanya. Pound menolak studi hukum sebagai studi tentang peraturan, melainkan keluar dari situ dan melihat efek dari hukum dan bekerjanya hukum. Tentang ini, dikatakan oleh Pound : "... to enable and to compel law making, and also interpretation and application of legal rules, to make more account, and more intellegent account, of the social fact upon which law must proceed and to which is to be applied. $^{3}$

Jerome Frank mengatakan bahwa tujuan utama penganut realisme hukum (legal realism) adalah untuk mebuat hukum :"menjadi lebih responsif terhadap kebutuhan sosial" untuk mencapai tujuan ini, mereka mendorong perluasan "bidang-bidang yang memiliki keterkaitan secara hukum". Agar pola pikir atau nalar hukum dapat mencakup pengetahuan di dalam konteks sosial dan memiliki pengaruh terhadap tindakan resmi para aparat hukum. Seperti halnya realisme hukum, sociological juresprudence juga ditunjukan untuk memberi kemampuan bagi institusi hukum, untuk secara lebih menyeluruh dan cerdas mempertimbangkan fakta-fakta sosial di mana hukum itu berproses dan diaplikasikan. Teori Pound mengenai kepentingan-kepentingan sosial merupakan sebuah usaha yang lebih eksplisit untuk mengembangkan suatu model hukum

2 Bernard L. Tanya, Yoan N. Simanjutak, Markus Y. Hage, 2013, Teori Hukum Strategi Tertib Manusia Lintas Ruang dan Generasi, Genta Publishing, Yogyakarta, Hal 140.

${ }^{3}$ Ibid, Hal 145 
responsif. Dalam presfektif ini, hukum yang baik seharusnya memberikan sesuatu yang lebih daripada sekedar prosedur hukum tersebut harus berkompeten dan juga adil. ${ }^{4}$

Sociological jurisprudence theory di atas diajadikan acuhan dalam menemukan problem yang terjadi dalam pencemaran dan atau perusakan lingkungan hidup dewasa ini. Meskipun sudah disediakan sanksi pidana yang diharapkan mampu untuk mencegah dan membuat jera bagi para pelaku namun kenyataannya tidak memiliki kekuatan untuk menghentikan tindakan pelaku pencemaran dan perusakan lingkungan hidup tersebut.

Dari teori hukum diatas alangkah lebih lengkapnya jika dipahaminya keberadaan hukum itu sendiri dalam masyarakat diperlukan suatu studi dengan pendekatan empirik dengan pendekatan non doktrinal sangat diperlukan adanya pengamatan mengenai peroperasinya hukum yang ada dalam realitas soaial. Dalam kaitan ini hukum dilihat sebagai sistem menurut Lawrence M. Friedman bahwa hukum terdiri dari tiga komponen yaitu pertama. Legal substance, yaitu norma-norma atau aturanaturan yang digunakan secara institusional beserta pola perilaku para pelaku dalam sistem hukum. Kedua, legal structure, yaitu lembagalembaga yang bertugas untuk menegakan hukum, seperti kepolisian, jaksa, hakim, advokat. Dan ketiga legal culture, yaitu kebiasaan, pandangan, cara bertindak dan berpikir dalam masyarakat umum yang dapat mempengaruhi kekuatankekuatan sosial menurut arah perkembangan tertentu. ${ }^{5}$

Pertanggungjawaban pidana dalam istilah asing tersebut juga dengan teorekenbaardheid atau criminal responsibility yang menjurus kepada pemidanaan petindak dengan maksud untuk menentukan apakah seseorang terdakwa

4 Philippe Nonet\&Philip Selznick, 2013, Hukum Responsif Pilihan di Masa Transisi, Perkumpulan Untuk Pembaharuan Hukum Berbasis Masyarakat dan Ekologis ( $\mathrm{Hu}$ Ma), Jakarta, Hal 59

${ }^{5}$ Lawrence L. Friedman, 1986, The Legal system: Social Science Prespektive, New Yoek, Russel Sage Foundation, Hal.17 atau tersangka dipertanggung jawabkan atas suatu tindakan pidana yang terjadi atau tidak.

Di dalam penjelasannya dikemukakan: Tindak pidana tidak berdiri sendiri, itu baru bermakna manakala terdapat pertanggungjawaban pidana. Ini berarti setiap orang yang melakukan tindak pidana tidak dengan sendirinya harus dipidana. Untuk dapat dipidana harus ada pertanggungjawaban pidana. Pertanggungjawaban pidana lahir dengan diteruskannya celaan (vewijbaarheid) yang objektif terhadap perbuatan yang dinyatakan sebagai tindak pidana yang berlaku, dan secara subjektif kepada pembuat tindak pidana yang memenuhi persyaratan untuk dapat dikenai pidana karena perbuatannya.

Dalam bahasa Belanda, istilah pertanggungjawaban pidana menurut Pompee terdapat padanan katanya, yaitu aansprakelijk, verantwoordelijk, dan toerekenbaar. Orangnya yang aansprakelijk atau verantwoordelijk, sedangkan toerekenbaar bukanlah orangnya, tetapi perbuatan yang dipertanggungjawaban kepada orang. Biasa pengarang lain memakai istilah toerekeningsvatbaar. Pompee keberatan atas pemakaian istilah yang terakhir, karena bukan orangnya tetapi perbuatan yang toerekeningsvatbaar.

Kebijakan menetapkan suatu sistem pertanggungjawaban pidana sebagai salah satu kebijakan kriminal merupakan persoalan pemilihan dari berbagai alternatif. Dengan demikian, pemilihan dan penetapan sistem pertanggungjawaban pidana tidak dapat dilepaskan dari berbagai pertimbangan yang rasional dan bijaksana sesuai dengan keadaan dan perkembangan masyarakat. Sehubungan dengan masalah tersebut di atas maka Romli Atmasasmita menyatakan sebagai berikut :

"Berbicara tentang konsep liability atau "pertanggungjawaban" dilihat dari segi falsafat hukum, seorang filosof besar dalam bidang hukum pada abad ke-20, Roscou Pound, dalam An Introduction to the Philosophy of Law, telah mengemukakan pendapatnya "I .... Use the simple word "liability" for the situation whereby one exact 
legally and other is legally subjected to the exaction.

Bertitik tolak pada rumusan tentang "pertanggungjawaban" atau liability tersebut diatas, Pound membahasnya dari sudut pandang filosofis dan sistem hukum secara timbal balik. Secara sistematis, Pound lebih jauh menguraikan perkembangan konsepsi liability. Teori pertama, menurut Pound, bahwa liability diartikan sebagai suatu kewajiban untuk membayar pembalasan yang akan diterima pelaku dari seseorang yang telah "dirugikan". Sejalan dengan semakin efektifnya perlindungan undang-undang terhadap kepentingan masyarakat akan suatu kedamaian dan ketertiban, dan adanya keyakinan bahwa "pembalasan" sebagai suatu alat penangkal, maka pembayaran "ganti rugi" bergeser kedudukannya, semula sebagai suatu "hak istimewa" kemudian menjadi suatu "kewajiban". Ukuran "ganti rugi" tersebu tidak lagi dari nilai suatu pembalasan yang harus "dibeli", melainkan dari sudut kerugian atau penderitaan yang ditimbulkan oleh perbuatan pelaku yang bersangkutan.

Pembicaraan mengenai pertanggungjawaban pidana tidak dapat dilepaskan dari pembicaraan mengenai perbuatan pidana. Orang tidak mungkin dipertanggungjawabkan untuk dipidana, apabila ia tidak melakukan tindak pidana. Para penulis sering menggambarkan bahwa dalam menjatuhkan pidana unsur " tindak pidana" dan "pertanggungjawaban pidana" harus dipenuhi.

Unsur tindak pidana dan kesalahan (kesengajaan) adalah unsur yang sentral dalam hukum pidana. Unsur perbuatan pidana terletak dalam lapangan objektif yang diikuti oleh unsur sifat melawan hukum, sedangkan unsur pertanggungjawaban pidana merupakan unsur subjektif yang terdiri dari kemampuan bertanggung jawab dan adanya kesalahan (kesengajaan dan kealpaan).

Indonesia merupakan negara dengan berbagai kekayaan alam yang menjadikan pertambangan sebagai salah satu roda perekonomian di Indonesia. ${ }^{6} \mathrm{Hal}$ tersebut menjadi landasan perlunya pengaturan yang terkait dengan pertambangan yang berubah untuk lebih disempurnakan seiring dengan perkembangan jaman dan teknologi. Sebelum diundangkannya Undang- $\underline{\text { Undang No }}$ No. 4 tahun 2009 tentang Pertambangan Mineral dan Batubara adalah Undang-Undang No. 11 tahun 1967 tentang Ketentuan-Ketentuan Pokok Pertambangan yang diundangkan oleh Presiden Soeharto pada tanggal 2 Desember 1967.

Perolehan nasional dari pertambangan dapat dikatakan multidimensional, yaitu antara lain mampu menompang program industrialisasi melalui penyediaan bahan baku bagi industri dalam negeri, mampu menyediakan sumber energi primer yang penting seperti minyak dan gas bumi serta batubara. Selain itu, sektor ini juga mampu meningkatkan penerimaan negara dan devisa, meningkatkan dan memeratakan pembangunan ke seluruh wilayah, membuka seluas-luasnya kesempatan berusaha dan bekerja serta meningkatkan kesejahteraan dan kualitas hidup bermasyarakat. Penggunaan sumber daya mineral dan energi sebagai salah satu modal dasar bangsa, diarahkan menjadi pendorong utama dan penggerak pembangunan ekonomi, termasuk sarana dan prasarananya. ${ }^{7}$

Sejak reformasi 1998, dapat kita lihat bahwa usaha pertambangan mengalami pasang surut mulai dari pengurusan perizinan tambang hingga pelaksanaan kuasa pertambangannya sudah mulai terindikasi adanya tindak pidana ekonomi. Mengingat bahwa karena industri pembangunan sektor pertambangan telah memberikan kontribusi yang sangat besar bagi pembangunan nasional, bahkan pertambangan merupakan komoditas andalan baik sebagai salah satu sumber energi primer maupun penyediaan anggaran pemerintah. ${ }^{8}$ Apabila telah adanya indikasi atau perbuatan tindak pidana ekonomi dalam pertambangan misalnya dalam tindak pidana perpajakan tentu kami

\footnotetext{
"Lihat Bloomberg, "Indonesian tin smelters resume output", The Business Times, 14 September 2012.

7 Abrar Saleng, Hukum Pertambangan, (Yogyakarta : UII Press, 2004), hal. 199

${ }^{8}$ Disadur dari Abrar Saleng, ibid
} 
dapat melihat betapa besar dampak kerugian perekonomian pendapatan negara, yang juga semakin membuat rakyat kecil sengsara.

Sebelum berlakunya otonomi daerah, pejabat yang berwenang memberikan izin kuasa pertambangan adalah pemerintah pusat, yang diwakili oleh Menteri Energi dan Sumber Daya Mineral (ESDM). Dengan berlakunya otonomi daerah kewenangan dalam pemberian izin tidak hanya menjadi kewenangan Menteri ESDM semata-mata, tetapi kini telah menjadi kewenangan pemerintah provinsi dan kabupaten kota. 9 Mengingat bahwa sejak munculnya Undang-Undang No. 32 Tahun 2004 Tentang Pemerintahan Daerah (UU Pemerintahan Daerah), dalam ketentuannya menyebutkan daerah diberikan kewenangan untuk mengelola sumber daya alam yang tersedia di wilayahnya. Kewenangan yang dimaksud telah diatur dalam Pasal 17 Undang-Undang Otonomi Daerah dan Pasal 4 Undang-Undang No. 4 Tahun 2009 Tentang Pertambangan.

Pengurusan izin pertambangan saat ini sudah mulai terindikasi adanya tindak pidana korupsi. Hal tersebut menurut Neta. S Pane, Ketua Presidium Indonesia Police Watch, mengatakan KPK perlu melakukan penyadapan maupun pengamatan kekayaan pejabat di daerah yang memiliki kawasan pertambangan batubara. Pejabat yang dimaksud adalah di tingkat eksekutif daerah maupun perwira penegak hukum, KPK harus memiliki strategi khusus terkait dengan penanganan dugaan korupsi di sektor pertambangan. Pemberian gratifikasi kepada pejabat daerah maupun penegak hukum sudah menjadi rahasia umum untuk wilayah yang kaya pertambangan. ${ }^{10}$

Adanya indikasi tindak pidana korupsi di bidang pertambangan selain karena isu pemberian gratifikasi juga karena adanya kebijakan pemerintahan daerah yang merugikan rakyat. Hal ini terjadi dikarenakan banyak izin

9 H. Salim. HS., Hukum Pertambangan di Indonesia, (Jakarta: PT. Rajagrafindo Persada, 2007), hal. 3

${ }_{10}$ Anugerah Perkasa, "Korupsi Tambang, KPK Didesak Pantau Pejabat Daerah", Senin 04 Juni 2012, http://www.bisnis.com/articles/korupsi-tambang-kpkdidesak-pantau-pejabat-daerah, diakses 20 Februari 2017. yang tidak jelas. Saat dimulai desentralisasi, dimana partai-partai butuh dana untuk melakukan kampanye. Biaya politik yang tinggi menimbulkan mekanisme politik Ijon. Dalam masa-masa mendekati pemilu, biasanya pengurusan izin pertambangan akan lebih mudah. Dimana izin-izin tersebut ada yang ilegal, dan ada yang legal (namun bersifat ilegal). Munculnya informal government, dimana izin perusahaan mudah dikeluarkan dengan syarat bisa mengeluarkan dana untuk pemilu. ${ }^{11}$

Dalam peraturan perundang-undang pertambangan baik yang lama tahun 1967 dan yang baru tahun 2009, tidak diatur mengenai definisi atau pengertian tindak pidana pertambangan yang diatur adalah ketentuan sanksi pidananya dan bentuk-bentuk pelanggaran dan kejahatan dalam pertambangan.

Definisi tindak pidana ekonomi dapat kita lihat dalam Undang-Undang Darurat RI No. 7 Tahun 1955. Tindak pidana ekonomi (selanjut TPE) adalah tindak pidana khusus dilihat dari perbuatan yang dilarang bukan subyek. Dalam arti sempit TPE sebagaimana diatur oleh Undang-Undang No. 7 Dar. 1955 bagaimana agar efektif perlindungan atas pelanggaran tindakan yang disebut secara tegas atas enam ketentuan di bidang "gecontroleerde", "prijsbehersing", "penimbunan barang-barang", "rijsterdonnantie", "kewajiban penggillingan padi", "devizen". Jadi apa yang dimaksud sebagai TPE apabia disebut undang-undang tertentu. Dengan Undang-Undang Darurat ini dibentuk pengadilan khusus ekonomi, korporasi dapat dihukum, hukum diperberat dan diperlukan hakim yang ahli di bidang ekonomi. ${ }^{12}$ Mencari bentuk penyelesaian hukum atau law enforcement yang tegas dan jelas terhadap kasus tindak pidana ekonomi dalam pertambangan memang tidaklah mudah.

\footnotetext{
11 "Diskusi Korupsi di Sektor Pertambangan", Minggu 03 Juni 2012, http://jurnalasri.blogspot.com/2012/06/diskusikorupsi-di-sektor-pertambangan.html, diakses 20 Februari 2017.

12 Luhut M.P. Pangaribuan, Silabus Tindak Pidana Ekonomi dan Tidak Pidana di Bidang Perekonomian, Program Pascasarjana Fakultas Hukum Universitas Indonesia, 2013.
} 
Walaupun Undang-Undang Pertambangan Lama 1967 dan Baru 2009 mengatur bentuk-bentuk kejahatan pertambangan beserta ketentuan pindananya namun penanganan kasus-kasus pertambangan tersebut memang tidak bisa hanya melibatkan satu atau dua pihak. Banyak pihak harus turun tangan untuk menyelamatkan pertambangan Indonesia agar dikelola untuk kesejahteraan rakyat. Moratorium pengeluaran IUP, perbaikan dan peninjauan regulasi serta pengawasan yang baik diharapkan dapat menjadi langkah efektif untuk segera ditempuh.

Selain adanya law enforcement yang jelas dan tegas tentu peran Komisi Pemberantasan Tindak Pidana Korupsi sebagai salah satu Pengadilan Khusus Ekonomi selain Pengadilan Umum tentu diharapkan untuk mampu dan mengusut segala bentuk kejahatan tindak pidana ekonomi dalam pertambangan karena kegiatan usaha pertambangan merupakan kegiatan usaha yang mampu menambah keuntungan negara karena Indonesia adalah negara yang kaya akan sumber daya alamnya dan apabila dikelola dengan baik oleh Pemerintah Indonesia dapat memberi manfaat dan dipergunakan sebesar-besarnya untuk kemakmuran rakyat. Maka dalam hal ini penyelesaian tindak pidana dalam bidang pertambangan yang terkait dengan kemakmuran rakyat indonesia maka perlu diterapkan sanksi pidana yang memiliki unsur premium remedium sehingga pemberian sanksi pidana selain juga memberikan efek jera tetapi juga dapat memberikan pemulihan kerugian yang diderita oleh masyarakat.

Aturan tentang pidana di dalam perundangundangan tentang pertambangan tidak terlepas dari dasar-dasar teori hukum pidana. Pertanggungjawaban dalam tindak pidana harus ada unsur-unsur tindak pidana yaitu adanya perbuatan yang dilarang, adanya akibat dari perbuatan itu dan adanya sifat melanggar hukum yang dimana ketiga unsur tersebut yang dilakukan oleh perorangan maupun badan hukum (korporasi). Berdasarkan hal tersebut kami mencoba untuk mengambil dan menganalisa ketentuan-ketentuan pidana dalam UndangUndang No. 11 Tahun 1967 tentang Ketentuan-
Ketentuan Pokok Pertambangan dan UndangUndang No. 4 Tahun 2009 tentang Pertambangan Mineral dan Batubara sebagai berikut:

1. Ketentuan pidana dalam Undang-Undang No.11 Tahun 1967 tentang KetentuanKetentuan Pokok Pertambangan adalah sebagai berikut:

a. Pasal 31 Ayat (1)

Dihukum dengan hukuman penjara selamalamanya enam tahun dan/ atau dengan denda setinggi-tingginya Rp. 500.000.000,00 (lima ratus ribu Rupiah), barang siapa yang tidak mempunyai kuasa pertambangan melakukan usaha pertambangan seperti dimaksud dalam pasal 14 dan 15.

b. Pasal 31 Ayat (2)

Dihukum dengan hukuman kurungan selama-lamanya satu tahun dan/ atau dengan denda setinggi-tingginya $R p$. 50.000,00 (lima puluh ribu Rupiah), sebelum memenuhi kewajiban-kewajiban terhadap yang berhak atas tanah menurut undang-undang ini.

c. Pasal 32 Ayat (1)

Dihukum dengan hukuman kurungan selama-lamanya satu tahun dan/ atau dengan denda setinggi-tingginya $R p$. $50.000,00$ (lima puluh ribu Rupiah), barangsiapa yang tidak berhak atas tanah merintangi atau mengganggu usaha pertambangan yang sah.

d. Pasal 32 Ayat (2)

Dihukum dengan hukuman kurungan selama-lamanya tiga bulan dan/ atau dengan denda setinggi-tingginya $R p$. $10.000,00$ (sepuluh ribu Rupiah), barang siapa yang berhak atas tanah merintangi atau mengganggu usaha pertambangan yang sah, setelah pemegang kuasa pertambangan memenuhi syarat-syarat sebagaimana yang tercantum dalam pasal 26 dan 27 undang-undang ini.

e. Pasal 33

Dihukum dengan hukuman kurungan selama-lamanya tiga bulan dan/ atau 
dengan denda setinggi-tingginya $\mathrm{Rp}$. $10.000,00$ (sepuluh ribu Rupiah) bagi:

i. Pemegang kuasa pertambangan yang tidak memenuhi atau tidak melaksanakan syarat-syarat yang berlaku menurut undang-undang ini dan/ atau undangundang termaksud dalam keputusan Menteri yang diberikan berdasarkan undang-undang ini dan/ atau undangundang yang termaksud dalam pasal 13.

ii. Pemegang kuasa pertambangan yang tidak melakukan perintah-perintah dan/ atau petunjuk-petunjuk yang berwajib berdasarkan undang-undang ini.

f. Pasal 34 Ayat (1)

Jikalau pemegang kuasa pertambangan atau wakilnya adalah suatu perseroan, maka hukuman termaksud pasal 31, 32 dan 33 dijatuhkan kepada para anggota pengurus.

9. Pasal 34 Ayat (2)

Tindak pidana yang dimaksud dalam pasal 31 ayat 1 adalah kejahatan dan perbuatan-perbuatan lainnya adalah pelanggaran.

2. Ketentuan pidana dalam Undang-Undang No.4 Tahun 2009 tentang Pertambangan Mineral dan Batubara adalah sebagai berikut:

a. Pasal 158

Setiap orang yang melakukan usaha penambangan tanpa IUP, IPR atau IUPK sebagaimana dimaksud dalam pasal 37, pasal 40 ayat (3), pasal 48 , pasal 67 ayat (1), pasal 74 ayat (1) atau ayat (5) dipidana dengan pidana penjara paling lama 10 (sepuluh) tahun dan denda paling banyak Rp. 10.000.000.000,00 (sepuluh miliar rupiah).

b. Pasal 159 Pemegang IUP, IPR, atau IUPK yang dengan sengaja menyampaikan laporan sebagaimana dimaksud dalam pasal 43 ayat (1), pasal 70 huruf e, pasal 81 ayat (1), pasal 105 ayat (4), pasal 110, atau pasal 111 ayat (1) dengan tidak benar atau menyampaikan keterangan palsu dipidana dengan pidana penjara paling lama 10 (sepuluh) tahun dan denda paling banyak Rp. 10.000.000.000,00 (sepuluh miliar rupiah).

c. Pasal 160 Ayat (1)

setiap orang yang melakukan eksplorasi tanpa memiliki IUP atau IUPK sebagaimana dimaksud dalam pasal 37 atau pasal 74 ayat (1) dipidana dengan pidana kurungan paling lama 1 (satu) tahun atau denda paling banyak Rp.200.000.000,00 (dua ratus juta rupiah).

d. Pasal 160 Ayat (2)

Setiap orang yang mempunyai IUP Eksplorasi tetapi melakukan kegiatan operasi produksi dipidana dengan pidana penjara paling lama 5 (lima) Tahun dan denda paling banyak Rp10.000.000.000,00 (sepuluh miliar rupiah).

e. Pasal 161

Setiap orang atau pemegang IUP Operasi Produksi atau IUPK Operasi Produksi yang menampung, memanfaatkan, melakukan pengolahan dan pemurnian, pengangkutan, penjualan mineral dan batubara yang bukan dari pemegang IUP, IUPK, atau izin sebagaimana dimaksud dalam pasal 37, pasal 40 ayat (3), pasal 43 ayat (2), pasal 48, pasal 67 ayat (1), pasal 74 ayat (1), pasal 81 ayat (2), pasal 103 ayat (2), pasal 104 ayat (3), atau pasal 105 ayat (1) dipidana dengan pidana penjara paling lama 10 (sepuluh) tahun dan denda paling banyak Rp. 10.000.000.000,00 (sepuluh miliar rupiah).

f. Pasal 162

Setiap orang yang merintangi atau mengganggu kegiatan usaha pertambangan dari pemegang IUP atau IUPK yang telah memenuhi syarat-syarat sebagaimana dimaksud dalam pasal 136 ayat (2) dipidana dengan pidana kurungan paling lama 1 (satu) tahun atau denda paling banyak Rp. 100.000.000,00 (seratus juta rupiah).

9. Pasal 163 Ayat (1)

Dalam hal tindak pidana sebagaimana dimaksud dalam bab ini dilakukan oleh 
suatu badan hukum, selain pidana penjara dan denda terhadap pengurusnya, pidana yang dapat dijatuhkan terhadap badan hukum tersebut berupa pidana denda dengan pemberatan ditambah $1 / 3$ (satu pertiga) kali dari ketentuan maksimum pidana denda yang dijatuhkan.

h. Pasal 163 Ayat (2)

Selain pidana denda sebagaimana dimaksud pada ayat (1), badan hukum dapat dijatuhi pidana tambahan berupa:

1) pencabutan izin usaha; dan/atau

2) pencabutan status badan hukum.

i. Pasal 164

Selain ketentuan sebagaimana dimaksud dalam pasal 158, pasal 159, pasal 160, pasal 161, dan pasal 162 kepada pelaku tindak pidana dapat dikenai pidana tambahan berupa:

1) perampasan barang;

2) perampasan keuntungan yang diperoleh dari tindak pidana;

3) kewajiban membayar biaya yang timbul akibat tindak pidana.

j. Pasal 165

Setiap orang yang mengeluarkan IUP, IPR, atau IUPK yang bertentangan dengan Undang-Undang ini dan menyalahgunakan kewenangannya diberi sanksi pidana paling lama 2 (dua) tahun penjara dan denda paling banyak Rp. 200.000.000,00 (dua ratus juta rupiah).

Berdasarkan hal yang sebagaimana dimaksud dalam sub-bab ini, maka diperoleh perbandingan antara UndangUndang No.11 Tahun 1967 tentang Ketentuan-Ketentuan Pokok Pertambangan dengan Undang-Undang No.4 Tahun 2009 tentang Pertambangan Mineral dan Batubara adalah sebagai berikut :

1. Melakukan kegiatan penambangan tanpa memiliki ijin dari pihak yang berwenang menurut UU 11 Tahun 67 dihukum dengan hukuman penjara selama-lamanya enam tahun dan/ atau dengan denda setinggi-tingginya Rp. $500.000 .000,00$ (lima ratus ribu Rupiah) sedangkan menurut UU 4 Tahun 2009 dipidana dengan pidana penjara paling lama 10 (sepuluh) tahun dan denda paling banyak Rp. 10.000.000.000,00 (sepuluh miliar rupiah), namun tambahan bagi pelaku yang melakukan eksplorasi tanpa memiliki IUP atau IUPK menurut UU 4 Tahun 2009 dipidana dengan pidana kurungan paling lama 1 (satu) tahun atau denda paling banyak Rp.200.000.000,00 (dua ratus juta rupiah) dan bagi yang mempunyai IUP Eksplorasi tetapi melakukan kegiatan operasi produksi dipidana dengan pidana penjara paling lama 5 (lima) Tahun dan denda paling banyak Rp10.000.000.000,00 (sepuluh miliar rupiah) dan yang melakukan tindak pidana yang dimaksud dalam angka ini dapat dikenai pidana tambahan berupa perampasan barang, perampasan keuntungan yang diperoleh dari tindak pidana dan kewajiban membayar biaya yang timbul akibat tindak pidana.

2. Melakukan kuasa pertambangan yang tidak memenuhi syarat-syarat yang ditetapkan atau menyampaikan keterangan palsu, menurut UU 11 Tahun 1967 dihukum dengan hukuman kurungan selama-lamanya tiga bulan dan/ atau dengan denda setinggi-tingginya $\mathrm{Rp}$. 10.000,00 (sepuluh ribu Rupiah), sedangkan menurut UU 4 Tahun 2009 adalah pidana penjara paling lama 10 (sepuluh) tahun dan denda paling banyak Rp. 10.000.000.000,00 (sepuluh miliar rupiah).

3. Apabila pelaku pelanggaran pertambangan merupakan Perseroan, menurut UU 11 Tahun 67 hukuman termaksud denda dan kurungan dijatuhkan kepada para anggota pengurus, sedangkan menurut UU 4 Tahun 2009 selain pidana penjara dan denda terhadap pengurusnya, pidana yang dapat dijatuhkan terhadap badan hukum tersebut berupa pidana denda dengan pemberatan ditambah $1 / 3$ (satu pertiga) kali dari ketentuan maksimum pidana denda yang dijatuhkan dan juga 
dapat dijatuhi pidana tambahan berupa pencabutan izin usaha dan/atau pencabutan status badan hukum.

4. Orang yang mengganggu usaha pertambangan yang sah menurut UU 11 Tahun 1967 dihukum dengan hukuman kurungan selama-lamanya satu tahun dan/ atau dengan denda setinggitingginya Rp. 50.000,00 (lima puluh ribu Rupiah) atau dikenakan hukuman kurungan selama-lamanya tiga bulan dan/ atau dengan denda setinggitingginya Rp. 10.000,00 (sepuluh ribu Rupiah), sedangkan menurut UU 4 Tahun 2009 dipidana dengan pidana kurungan paling lama 1 (satu) tahun atau denda paling banyak Rp. 100.000.000,00 (seratus juta rupiah).

5. Apabila pelaku pertambangan tidak memenuhi kewajiban-kewajiban terhadap yang berhak atas tanah, menurut UU 11 Tahun 1967 dihukum dengan hukuman kurungan selamalamanya satu tahun dan/ atau dengan denda setinggi-tingginya Rp. $50.000,00$ (lima puluh ribu Rupiah), sedangkan dalam UU 4 Tahun 2009 tidak diatur.

6. Menurut UU 11 Tahun 1967 tindak pidana yang dimaksud dalam pasal 31 ayat 1 tentang penambangan tanpa izin adalah kejahatan dan perbuatanperbuatan lainnya adalah merupakan pelanggaran, sedangkan dalam UU 4 Tahun 2009 tidak diatur.

7. Menurut UU 4 Tahun 2009 setiap orang atau pemegang IUP Operasi Produksi atau IUPK Operasi Produksi yang menampung, memanfaatkan, melakukan pengolahan dan pemurnian, pengangkutan, penjualan mineral dan batubara yang bukan dari pemegang IUP, IUPK dipidana dengan pidana penjara paling lama 10 (sepuluh) tahun dan denda paling banyak Rp. 10.000.000.000,00 (sepuluh miliar rupiah), sedangkan dalam UU 11 Tahun 1967 tidak diatur.
8. Menurut UU 4 Tahun 2009 bahwa setiap orang yang mengeluarkan IUP, IPR, atau IUPK yang bertentangan dengan undang-undang ini dan menyalahgunakan kewenangannya diberi sanksi pidana paling lama 2 (dua) tahun penjara dan denda paling banyak Rp. 200.000.000,00 (dua ratus juta rupiah), sedangkan dalam UU 11 Tahun 1967 tidak diatur.

Berangkat daripada hal-hal yang tercantum dalam sub-bab ini, kami menemukan beberapa perbedaan yang terkait dengan ketentuan pidana pada Undang-undang Nomor 11 Tahun 1967 tentang Ketentuan-Ketentuan Pokok Pertambangan dengan Undang-undang Nomor 4 Tahun 2009 tentang Pertambangan Mineral dan Batubara mengenai hukuman pidana kurungan dan pidana penjara selain daripada pidana denda yang mana masing-masing dari undang-undang tersebut menerapkan hal yang sama.

Dalam Pasal 10 Kitab Undang-Undang Hukum Pidana dijelaskan mengenai pidana yang terdiri dari:

1. Pidana Pokok yang terdiri atas:
a. pidana mati;
b. pidana penjara;
c. pidana kurungan;
d. pidana denda;
e. pidana tutupan.

2. Pidana Tambahan yang terdiri atas:
a. pencabutan hak-hak tertentu;
b. perampasan barang-barang tertentu;
c. pengumuman putusan hakim.

Berbicara mengenai pidana sudah barang tentu bahwa kita mengenal asas "nullum delictum nula poena sine praevia lege poenali" yang berarti suatu perbuatan tidak dapat dipidana, kecuali berdasarkan kekuatan ketentuan perundang-undangn pidana yang telah ada. ${ }^{13}$ Sehubungan dengan Undang-undang Nomor 11 Tahun 1967 tentang KetentuanKetentuan Pokok Pertambangan dan Undang-

\footnotetext{
${ }^{13}$ Lihat Pasal 1 ayat 1 dari Kitab Undang-Undang Hukum Pidana
} 
undang Nomor 4 Tahun 2009 tentang Pertambangan Mineral dan Batubara, kami melihat adanya perbedaan yang cukup mendasar antara pidana kurungan dan pidana penjara. Dilihat dari segi jangka waktu, pidana penjara dapat dikenakan seumur hidup atau selama waktu tertentu, waktu tertentu tersebut paling singkat adalah satu hari dan paling lama dan tidak boleh melebihi dua puluh tahun ${ }^{14}$, sedangkan pidana kurungan paling singkat adalah 1 hari dan paling lama adalah satu tahun empat bulan ${ }^{15}$.

\section{KESIMPULAN}

Berdasarkan uraian kami di atas, kami berkesimpulan bahwa Undang-Undang No.11 Tahun 1967 tentang Ketentuan-Ketentuan Pokok Pertambangan dan Undang-Undang Nomor 4 Tahun 2009 tentang Pertambangan Mineral dan Batu Bara menerapkan asas premium remedium $\mathrm{Hal}$ itu terlihat dari isi dan penjelasan umum dari kedua undang-undang tersebut tidak mencantumkan bahwa kedua undang-undang tersebut menganut asas ultimum remedium. Sejalan dengan doktrin hukum pidana yaitu ultimum remedium artinya sanksi pidana merupakan pilihan terakhir dalam mencegah terjadinya pelanggaran di bidang pertambangan. Untuk mencapai sarana penyelesaian sengketa di dalam bidang pertambangan jika ingin memberikan efek jera (premium remedium) atau memberikan penyadaran pada pelaku kejahatan bisnis maka lebih baik diterapkan sanksi pidana seberat beratnya bagi pelaku kejahatan pertambangan tersebut.

\section{REKOMENDASI}

Pendirikan industri pertambangan di Indonesia harus terpenuhi ijin yang berlaku dan jangan melakukan kegiatan pertambangan diluar ketentuan ijin karena akan menimbulkan dampak kerusakan lingkungan yang luar biasa.

${ }^{14}$ Lihat Pasal 12 ayat 1, 2, dan 4 dari Kitab Undang-Undang Hukum Pidana

${ }^{15}$ Lihat Pasal 18 ayat 1 dan 3 dari Kitab UndangUndang Hukum Pidana

\section{DAFTAR PUSTAKA}

Abrar Saleng, 2004, Hukum Pertambangan, UII Press, Yogyakarta.

Bernard L. Tanya, Yoan N. Simanjutak, Markus Y. Hage, Teori Hukum Strategi Tertib Manusia Lintas Ruang dan Generasi, Genta Publishing, Yogyakarta, 2013.

H. Salim. HS., 2007, Hukum Pertambangan di Indonesia, Rajagrafindo Persada, Jakarta

Lamintang , P. A. F., Dasar-dasar Hukum Pidana Indonesia, Bandung: Sinar Baru

Lawrence L. Friedman, The Legal system: Social Science Prespektive, New Yoek, Russel Sage Foundation, 1986

Luhut M.P. Pangaribuan, 2013, Silabus Tindak Pidana Ekonomi dan Tidak Pidana di Bidang Perekonomian, Program Pascasarjana Fakultas Hukum Universitas Indonesia.

Masriani, Yulies Tiena, S.H. M.Hum. Pengantar Hukum Indonesia, Jakarta: Sinar Grafika, , cet II, 2006.

Philippe Nonet\&Philip Selznick, Hukum Responsif Pilihan di Masa Transisi, Perkumpulan Untuk Pembaharuan Hukum Berbasis Masyarakat dan Ekologis ( $\mathrm{Hu}$ Ma), Jakarta, 2013

Roescoe Pound, An Introduction to the Philosophy of Law, New Haven, Yale University Press, 1961

Saleng, Abrar, Hukum Pertambangan, Yogyakarta: UII Press, 2004.

Salim, H. HS., Hukum Pertambangan di Indonesia, Jakarta: PT. Rajagrafindo Persada, 2007. 